\title{
A high-protein diet containing inulin/oligofructose supports body weight gain associated with lower energy expenditure and carbohydrate oxidation, and alters faecal microbiota in C57BL/6 mice
}

\author{
Franziska Koch ${ }^{1}$, Michael Derno ${ }^{1}$, Martina Langhammer ${ }^{2}$, Armin Tuchscherer ${ }^{3}$, Harald M. Hammon ${ }^{1}$, \\ Manfred Mielenz ${ }^{1}$, Cornelia C. Metges ${ }^{1}$ and Björn Kuhla ${ }^{1} *$ \\ ${ }^{1}$ Institute of Nutritional Physiology "Oskar Kellner”, Institute for Farm Animal Biology (FBN), Wilhelm-Stabl-Allee 2, 18196 Dummerstorf, \\ Germany \\ ${ }^{2}$ Institute of Genetics and Biometry, Service Group Lab Animal Facility, Institute for Farm Animal Biology (FBN), Wilhelm-Stabl-Allee 2, 18196 \\ Dummerstorf, Germany \\ ${ }^{3}$ Institute of Genetics and Biometry, Livestock Genetics and Breeding Unit, Institute for Farm Animal Biology (FBN), Wilhelm-Stabl Allee 2, \\ 18196 Dummerstorf, Germany
}

(Received 10 March 2021 - Final revision received 4 June 2021 - Accepted 17 June 2021)

Journal of Nutritional Science (2021), vol. 10, e50, page 1 of 11

doi:10.1017/jns.2021.42

Abstract

Prebiotic supplements and high-protein (HP) diets reduce body weight and modulate intestinal microbiota. Our aim was to elucidate the combined effect of an inulin/oligofructose (FOS) and HP diet on body weight gain, energy metabolism and faecal microbiota. Forty male C57BL/6NCrl mice were fed a control (C) diet for 2 weeks and allocated to a C or HP (40\% protein) diet including no or $10 \%$ inulin/FOS (C + I and HP + I) for 4 weeks. Inulin/FOS was added in place of starch and cellulose. Body weight, food intake, faecal energy and nitrogen were determined. Indirect calorimetry and faecal microbiota analysis were performed after 3 weeks on diets. Body weight gain of HP-fed mice was $36 \%$ lower than HP + I- and C-fed mice $(P<0 \cdot 05)$. Diet digestibility and food conversion efficiency were higher in HP $+\mathrm{I}$ - than HP-fed mice $(P<0 \cdot 01)$, while food intake was comparable between groups. Total energy expenditure (heat production) was $25 \%$ lower in HP + I- than in C-, HP- and C + I-fed mice $(P<0 \cdot 001)$. Carbohydrate oxidation tended to be $24 \%$ higher in HP- than in HP + I-fed mice $(P<0 \cdot 05)$. Faecal nitrogen excretion was $31-45 \%$ lower in C-, C + I- and HP + I- than in HPfed mice $(P<0 \cdot 05)$. Faecal Bacteroides-Prevotella DNA was $2 \cdot 3$-fold higher in $\mathrm{C}+\mathrm{I}$ - and $\mathrm{HP}+\mathrm{I}$ - relative to $\mathrm{C}$-fed mice $(P<0 \cdot 05)$, but Clostridium leptum DNA abundances was $79 \%$ lower in HP + I- than in HP-fed mice $(P<0 \cdot 05)$. We suggest that the higher conversion efficiency of dietary energy of $\mathrm{HP}+\mathrm{I}$ but not $\mathrm{C}+\mathrm{I}$-fed mice is caused by higher digestibility and lower heat production, resulting in increased body mass.

Key words: Energy expenditure: High-protein diet: Inulin: Microbiota: Nitrogen excretion

\section{Introduction}

Prebiotics and high-protein (HP) diets are considered as 'functional foods' with potential health benefits ${ }^{(1)}$. Prebiotics, such as inulin and oligofructose (FOS), are defined as non-digestible dietary fibre ${ }^{(2)}$ and are naturally present as plant storage carbohydrates in, e.g., chicory roots, onions or bananas ${ }^{(3)}$. In mice, inulin is fermented in the distal colon and FOS in the caecum and proximal colon ${ }^{(4)}$, inducing beneficial alterations of the gut microbiota ${ }^{(5)}$. Inulin and FOS promote the growth of Lactobacilli and Bifidobacteria in rodents $^{(6)}$ and humans ${ }^{(2)}$, thereby improving the gut

Abbreviations: C: control; COX: carbohydrate oxidation; EB: energy balance; FOS: oligofructose; FOX: fat oxidation; HP: high protein; RQ: respiratory quotient; TEE: total energy expenditure; $+\mathrm{I}$ : inulin/oligofructose

*Corresponding author: Björn Kuhla, email b.kuhla@fbn-dummerstorf.de 
health of the host, e.g. by supporting the digestion and absorption of nutrients and minerals, inhibiting pathogenic bacteria or stimulating gastrointestinal immune functions ${ }^{(2)}$. Furthermore, FOS serves as an energy source for polysaccharide-cleaving bacteria, e.g. Bacteroides, which, however, require an additional nitrogen $(\mathrm{N})$ source for protein synthesis ${ }^{(2,7)}$. Supplementing a diet for rodents with $7.5 \%$ FOS or xylo-oligosaccharide (XOS) and gum arabic increased faecal $\mathrm{N}$ losses and reduced renal $\mathrm{N}$ excretion ${ }^{(8)}$. Furthermore, prebiotics increases gastric filling and intestinal motility and reduces body weight due to increased satiety in humans and rodents ${ }^{(9-11)}$. As a potential negative effect, ingestion of high amounts $(>15 \mathrm{~g} / \mathrm{d})$ of inulin induces flatulence, abdominal pain and bloating in humans, which may limit the long-term application of inulin and FOS at high concentrations in the $\operatorname{diet}^{(12,13)}$.

Diets with a high protein (30-55\%) but low carbohydrate content promote body weight loss ${ }^{(14)}$ and increase muscle mass ${ }^{(15)}$, but also induce oxidative stress ${ }^{(16)}$. In mice, feeding a $60 \%$ HP diet for 12 weeks reduced body weight by $21 \%$ and fat mass by $39 \%$ compared with a control diet containing $20 \%$ protein ${ }^{(17)}$. After 8 weeks of ingestion of a $28 \%$ proteinrich diet, non-obese humans reduced their body weight and fat mass by 3 and $9 \%$, respectively ${ }^{(18)}$. In overweight women, a $30 \%$ HP-high-fibre diet, with fibres originating from oats, legumes, nuts, dried fruits, whole-grain breads and cereals (>35 g fibre/d), reduced body weight gain after 10 weeks compared with the control diet ${ }^{(19)}$. The reduction in body weight of non-obese rats fed with a $55 \%$ HP diet might be linked to the inhibition of de novo lipogenesis limiting fat mass deposition ${ }^{(20)}$, but increasing thermogenesis and energy expenditure is another possibility ${ }^{(21,22)}$. The thermic effect of dietary protein is the highest compared to that of the other macronutrients ${ }^{(22)}$. In diets with the higher protein content $(25-55 \%)$, greater thermogenesis and energy expenditure were only found during the first 2-4 weeks of feeding, but not when HP diets were fed for 6 weeks and longer to rodents ${ }^{(23,24)}$ and humans ${ }^{(25,26)}$. Thus, thermogenesis seems to be stimulated shortly after the initiation of HP diet feeding. High-protein diets may also influence gut microbiota composition $^{(27,28)}$. In the colon, undigested proteins are metabolised by the microbiota, predominantly involving proteolytic bacteria such as Bacteriodes in human faecal inoculates ${ }^{(29)}$. In rodents, feeding an HP diet (53\% protein) for $15 \mathrm{~d}$ compared to a control diet (14\% protein) reduced the abundance of Clostridium coccoides group and Clostridium leptum group in the large intestine ${ }^{(30)}$

Taken together, consumption of an HP diet or inulin supplementation has been shown to reduce body weight and affect large intestinal microbiota. We hypothesised that consumption of an HP diet containing inulin/FOS has additive beneficial effects on body weight reduction involving mechanisms related to digestibility and energy metabolism. The objectives of the present study were to investigate the effects of inulin/FOS included in an HP (40\% protein) compared to a control (18\% protein) diet on body weight gain, apparent $\mathrm{N}$ and energy digestibility, food conversion efficiency, energy expenditure, nutrient oxidation and abundance of selected
Table 1. Food composition and macronutrient contents of the experimental diets

\begin{tabular}{|c|c|c|c|c|}
\hline Ingredients (g/kg DM $\left.{ }^{1}\right)$ & $\mathrm{C}$ & $C+1$ & $\mathrm{HP}$ & $\mathrm{HP}+\mathrm{I}$ \\
\hline Casein & $200 \cdot 0$ & $200 \cdot 0$ & $454 \cdot 0$ & $454 \cdot 0$ \\
\hline Corn starch & $397 \cdot 5$ & 337.5 & 173.5 & $103 \cdot 5$ \\
\hline Maltodextrin & $132 \cdot 0$ & $122 \cdot 0$ & $100 \cdot 0$ & $100 \cdot 0$ \\
\hline Sucrose & $100 \cdot 0$ & $100 \cdot 0$ & $100 \cdot 0$ & $100 \cdot 0$ \\
\hline Cellulose powder & $50 \cdot 0$ & $20 \cdot 0$ & $50 \cdot 0$ & $20 \cdot 0$ \\
\hline L-Cysteine & $3 \cdot 0$ & $3 \cdot 0$ & $5 \cdot 0$ & $5 \cdot 0$ \\
\hline Vitamin premix & $10 \cdot 0$ & $10 \cdot 0$ & $10 \cdot 0$ & $10 \cdot 0$ \\
\hline Mineral premix & $35 \cdot 0$ & $35 \cdot 0$ & $35 \cdot 0$ & $35 \cdot 0$ \\
\hline Choline Chloride & $2 \cdot 5$ & 2.5 & $2 \cdot 5$ & $2 \cdot 5$ \\
\hline Inulin/FOS $(1: 1)^{2,3}$ & - & $100 \cdot 0$ & - & $100 \cdot 0$ \\
\hline Soyabean oil & $70 \cdot 0$ & $70 \cdot 0$ & $70 \cdot 0$ & $70 \cdot 0$ \\
\hline \multicolumn{5}{|l|}{ Nutrient composition ${ }^{4}$ (g/kg DM) } \\
\hline Crude protein & $186 \cdot 0$ & $187 \cdot 0$ & $428 \cdot 0$ & $429 \cdot 0$ \\
\hline Crude fat & $74 \cdot 0$ & $74 \cdot 0$ & $78 \cdot 0$ & $78 \cdot 0$ \\
\hline Crude fibre & $52 \cdot 0$ & $120 \cdot 0^{1}$ & $53 \cdot 0$ & $122 \cdot 0^{1}$ \\
\hline Crude ash & $34 \cdot 0$ & $34 \cdot 0$ & $36 \cdot 0$ & $36 \cdot 0$ \\
\hline Starch & $400 \cdot 0$ & $341 \cdot 0$ & $178 \cdot 4$ & $107 \cdot 0$ \\
\hline Sucrose & $117 \cdot 0$ & $118 \cdot 0$ & $120 \cdot 0$ & $121 \cdot 0$ \\
\hline Dextrin & $137 \cdot 0$ & $127 \cdot 0$ & $106 \cdot 0$ & $106 \cdot 0$ \\
\hline Carbohydrate $5 /$ fat ratio & $8 \cdot 8$ & $7 \cdot 9$ & $5 \cdot 2$ & $4 \cdot 3$ \\
\hline Measured gross energy ${ }^{6}(\mathrm{MJ} / \mathrm{kg})$ & $18 \cdot 0$ & $18 \cdot 0$ & $19 \cdot 6$ & $19 \cdot 6$ \\
\hline
\end{tabular}

${ }^{1} \mathrm{DM}$, dry matter.

${ }^{2}$ Inulin/FOS calculated with $94 \%$ crude fibre.

${ }^{3}$ Orafti®HP inulin and Orafti®L95(Beneo).

${ }^{4}$ Calculated nutrient composition.

${ }^{5}$ Carbohydrates $=$ starch + sucrose + dextrin.

${ }^{6}$ Energy content was measured by bomb calorimetry.

faecal microbiota known to be involved in non-digestible dietary fibre degradation.

\section{Experimental methods}

\section{Animals and diets}

Five-week-old male C57BL/6NCrl mice were individually housed in Macrolon cages Type II (Ebeco, Castrop-Rauxel, Germany) at $22^{\circ} \mathrm{C}$, with a $12: 12 \mathrm{~h}$ light-dark cycle (06.0018.00 light). Mice were randomly assigned and fed a control diet (C; AIN-93G) for 2 weeks (adaptation phase). Subsequently, mice were switched to one of four experimental diets ( $n 10$ animals per diet): C, C with $10 \%$ inulin/oligofructose (1: 1, C + I; Orafti ${ }^{\circledR H P}$ inulin and Orafti ${ }^{\circledR L} 95$; Beneo, Mannheim, Germany), high-protein diet (HP; $40 \%$ energy from protein) or HP diet including $10 \%$ inulin/oligofructose (1: $1, \mathrm{HP}+\mathrm{I})$ for a total of 4 weeks (experimental phase; Table 1). In C + I and HP + I diets, portions of starch and cellulose were substituted by inulin/FOS. Complete substitution of inulin/FOS by the non-digestible fibre cellulose only was not possible because diets were ought to be isoenergetic. However, the bomb calorimetry analysis (see later) revealed an $8.8 \%$ difference in energy content between $\mathrm{C} / \mathrm{C}+\mathrm{I}$ and $\mathrm{HP} / \mathrm{HP}+\mathrm{I}$ diets. The diets were purchased from ssniff Spezialdiäten $\mathrm{GmbH}$ (Soest, Germany) and stored at $4^{\circ} \mathrm{C}$ until use. Mice had free access to water and food. Body weight and food intake were measured daily (from Monday to Friday) by the third week of the experimental phase (days (d) 15-36). The mean of daily food, dry matter (DM), crude protein, crude fat, crude fibre, carbohydrates and the carbohydrate/fat intake 
ratio were calculated from days 15 to 36. The daily body weight gain was calculated by subtracting the mean body weight determined on days 11 and 12 from the body weights measured during days 15-36. The food conversion efficiency was calculated as body weight gain per energy intake ( $\mathrm{g}$ BW/MJ), based on the data from the three-week feeding period $^{(31)}$. The carbohydrate/fat intake ratio was calculated based on the individual carbohydrate and fat intake. The experimental protocol followed was approved by the licencing authority State Office for Agriculture, Food Safety and Fishing Mecklenburg-Western Pomerania, Germany (LALLF M-V/ TSD/7221.3-1-050/16).

\section{Energy expenditure and nutrient oxidation}

In the fourth week of feeding the experimental diets, mice were adapted for a period of $2 \mathrm{~h}$ on two different days to the respiration chambers before indirect calorimetry measurements. After acclimation, mice were placed in the respiration chambers with $20 \mathrm{~g}$ of the experimental diets and $50 \mathrm{ml}$ of water. Indirect calorimetry was performed at $22^{\circ} \mathrm{C}$ with 12:12 h dark-light cycle (06.00-18.00 light) to measure total energy expenditure and carbohydrate and fat oxidation as previously described ${ }^{(32)}$. Physical activity was recorded by an infrared motion detector converting movements into the numbers of impulses per time interval (i.e. $21 \mathrm{~min}$ ). Data were collected using Simatic hardware and Win CC software (Siemens AG, Munich, Germany). Food and water intake were recorded over $48 \mathrm{~h}$. The body weight was determined before and after gas exchange measurements to calculate the mean body weight. The daily total energy expenditure (TEE or heat production) was calculated according to Weir: TEE $(\mathrm{kJ})=$ $16.29 \times \mathrm{VO}_{2}+4.57 \times \mathrm{VCO}_{2}{ }^{(33)}$, where $\mathrm{VO}_{2}$ is the oxygen consumption $(\mathrm{l} / \mathrm{d})$ and $\mathrm{VCO}_{2}$ is the $\mathrm{CO}_{2}$ production $(\mathrm{l} / \mathrm{d})$. Net oxidation rates of fat (FOX) and carbohydrates (COX) were calculated according to Simonson and DeFronzo: FOX $(\mathrm{g})=1.69 \times\left(\mathrm{VO}_{2}-\mathrm{VCO}_{2}\right)$ and $\mathrm{COX}(\mathrm{g})=4.57 \times \mathrm{VCO}_{2}-$ $3 \cdot 23 \times \mathrm{VO}_{2}{ }^{(34)}$. The respiratory quotient (RQ) was calculated as the ratio of $\mathrm{VCO}_{2}$ to $\mathrm{VO}_{2}$, and the daily means for the 48-h measuring period were calculated. The energy balance (EB) was calculated: EB $(\mathrm{kJ})=$ energy intake $(\mathrm{kJ})$ - faecal energy $(\mathrm{kJ})$ - TEE $(\mathrm{kJ})$. One animal per group (except for $\mathrm{C}$ ) was removed from the evaluation because of technical problems with the respiration chambers.

\section{Faecal and dietary N content, and gastrointestinal transit time}

The faeces excreted over the 48-h period in the respiration chambers was collected and dried at $60^{\circ} \mathrm{C}$ for $24 \mathrm{~h}$. Faecal and dietary $\mathrm{N}$ were determined by elemental analysis (CE-Instruments, Flash EA 1112 series, ThermoQuest, Basingstoke, UK). Apparent $\mathrm{N}$ digestibility was estimated by the following equation: apparent $\mathrm{N}$ digestibility $(\%)=($ dietary $\mathrm{N}(\mathrm{g})$ - excreted faecal $\mathrm{N}(\mathrm{g})) \times 100 /$ dietary $\mathrm{N}(\mathrm{g})^{(35)}$. Three days after the indirect calorimetry experiment, mice were gavaged with $120 \mu \mathrm{l}$ of Carmine red $(10 \mathrm{mg} / \mathrm{ml}$ in drinking water) ${ }^{(35)}$, and the time of the expulsion of the first red faecal pellet was determined in a subset of five animals per diet.

\section{Calorimetric measurements}

Faecal and diet samples were dried and ground. Faecal samples from two to three mice per diet were pooled yielding approximately $1 \mathrm{~g}$. The energy content of the diets and faecal samples were analysed by bomb calorimetry (IKA C5003; IKA Werke, Staufen, Germany) as previously described ${ }^{(36)}$. The digestibility of the diet was calculated by Weitkunat et al: digestibility $(\%)=(($ dietary energy intake $(\mathrm{kJ} / 2 \mathrm{~d})-$ faecal energy excretion $(\mathrm{kJ} / 2 \mathrm{~d})) /$ dietary energy intake $(\mathrm{kJ} / 2 \mathrm{~d})) \times$ $100^{(36)}$

\section{Quantification of faecal microbiota by RT-qPCR}

Fresh faecal samples were taken in the fourth week of feeding the experimental diets and stored at $-20^{\circ} \mathrm{C}$ until DNA isolation. Genomic DNA was extracted with $700 \mu$ DNA extraction buffer from $70 \mathrm{mg}$ frozen faeces with mechanical disruption (bead-beating for $2 \times 45 \mathrm{~s}$ at $6500 \mathrm{rpm} ; 1.4 \mathrm{~mm}$ Precellys ceramic beats (Bertin Instruments, Montigny-leBretonneux, France)) using a QIAamp DNA stool mini kit (Qiagen, Hilden, Germany). DNA quality was verified on an agarose gel and the concentration was quantified using a NanoPhotometer (IMPLEM, Munich, Germany). Quantitative PCR was performed using the oligonucleotide primers (Supplementary Table S1 of Supplementary material). One PCR reaction was performed with $2 \mu \mathrm{l}$ of diluted DNA $(7.5 \mathrm{ng} / \mu \mathrm{l}), 0.5 \mu \mathrm{l}$ of each primer $(10 \mathrm{pmol}), 6 \mu \mathrm{l} 2 \times$ buffer SensiFAST SYBR No-ROX mix (Bioline, Luckenwalde, Germany) and $3 \mu \mathrm{l} \mathrm{H}_{2} \mathrm{O}$ PCR grade. Amplifications were detected on a Light Cycler 96 (Roche, Basel, Switzerland). One primer pair was designed to detect the bacterial $16 \mathrm{~S}$ rRNA gene, and its amount was utilised to normalise amplicon expression ${ }^{(37)}$. The efficiency of amplification was calculated using LinRegPCR software, version 2014.4 (Academic Medical Centre, Amsterdam, Netherlands ${ }^{(38)}$, yielding efficiency values were between 1.75 and 1.85 (Supplementary Table S1 of Supplementary material). The genus Lactobacillus was reclassified in March 2020 ${ }^{(39)}$. However, the primers used to detect all Lactobacillaceae classified as such until 2020. Data were quantified by qbasePlus software (Biogazelle, Gent, Belgium).

\section{Statistical analysis}

For the study design, a power analysis was performed with CADEMO software (Windows ANOVA F-test version 4.03, 2000; BioMath GmbH, Rostock) to determine the minimum difference $d$ according to $d=c_{d} * \sigma$, in which the following parameters were selected: residual standard deviation $\sigma 0 \cdot 6$; $c_{d} 1$; type one error $\alpha 0.05$ and type two error $\beta 0 \cdot 2$. For each parameter, the same relative accuracy was assumed. Authors who performed statistical analyses were aware of the group allocation at all stages of the experiment. Daily measurements on the same animal were analysed by repeated measurement ANOVA using the MIXED procedure of SAS (Version 9.4, SAS Institute Inc., Cary, NC, USA). The model contained the fixed effects dietary protein level 
(C, HP), inulin/FOS $(-\mathrm{I},+\mathrm{I})$, time (experimental day), and their interactions $\mathrm{HP} \times \mathrm{I}, \mathrm{HP} \times$ time, $\mathrm{I} \times$ time, $\mathrm{HP} \times \mathrm{I} \times$ time; and age and initial body weight on day 1 served as covariates. Repeated measures on the same animal were considered by the repeated statement of proc MIXED (repeated variable: time) using an autoregressive type for the block diagonal residual covariance matrix. Least-squares means (LSM) and their standard errors (SE) were computed for each fixed effect in the ANOVA model. Additionally, differences of these LSM were tested using the Tukey-Kramer procedure. The SLICE statement of proc MIXED was used for performing a partitioned analysis of the LSM for the interactions $\mathrm{HP} \times \mathrm{I}, \mathrm{HP} \times$ time, $\mathrm{I} \times$ time and $\mathrm{HP} \times \mathrm{I} \times$ time. Effects of diets measured on a single time point (digestibility, faecal $\mathrm{N}$ excretion, physical activity and microbiota) were evaluated by ANOVA using the MIXED procedure with the fixed effect dietary protein level (C and HP), inulin/FOS $(-\mathrm{I}$ and $+\mathrm{I})$ and age as a covariate in the model, and multiple comparisons between the dietary group levels were done using the TukeyKramer procedure. The results of energy metabolism (TEE, COX, FOX, RQ and EB) were tested for body weight differences using ANCOVA test ${ }^{(40)}$, and mean body weight during indirect calorimetry measurement was added as a covariate into the model, thereby accounting for eventual differences in body composition between groups. Spearman correlation coefficient between microbiota abundances, RQ, energy expenditure, apparent $\mathrm{N}$ digestibility and faecal $\mathrm{N}$ excretion was calculated by the CORR procedure of SAS. Results were considered statistically significant at $P<0.05$.

\section{Results}

\section{Body weight, body weight gain, food and energy intake}

During the 2-week adaptation phase on the C diet, the HP + I group had a higher food intake than the $\mathrm{C}$ group on days 4 and 11 (Fig. 1(a)). On day 12, HP + I-fed mice had higher body weight than $\mathrm{C}$-fed mice. After transfer to the experimental diets, $\mathrm{C}+\mathrm{I}$ - and $\mathrm{HP}+\mathrm{I}$-fed mice reduced food and energy intake compared to $\mathrm{C}$-fed mice on the first day $(P<0.05$, respectively), but not during the following 3 weeks (days 1536) of experimental diet feeding (Fig. 1(a) and (b)). From days 29 to 36, HP + I-fed mice had a significantly higher body weight than HP-fed mice $(P<0 \cdot 05$; Fig. 1(b)). On day 36, HP + I-fed mice showed higher body weight than C-fed mice $(P<0 \cdot 05$, Fig. $1(b))$. Because the body weight on day 12 differed between HP + I- and C-fed mice, the body weight gain before and after the switch to one of the four experimental diets was calculated. The body weight gain in $\mathrm{C}-$ and $\mathrm{C}+$ I-fed mice did not differ, whereas C- and HP + I-fed mice gained significantly more body weight than HP-fed mice in the third week (day 32-36) on the experimental diets $(P<$ $0 \cdot 05$, respectively; Fig. 1 (d)). The cumulative food intake did not differ among the groups. Calculating the intake of food and macronutrients as the daily mean of days $15-36$ in the experimental phase revealed that food, DM, fat and energy intake did not differ between groups (Table 2). However, carbohydrate intake was higher in both C- compared to
HP-dietary groups, but lower in $\mathrm{C}+\mathrm{I}-$ and $\mathrm{HP}+\mathrm{I}$ - than $\mathrm{C}$ - and HP-fed counterparts, respectively $(P<0 \cdot 05)$. The protein intake was higher in the HP than in $\mathrm{C}$ diets, irrespective of inulin/FOS content $(P<0 \cdot 05$, respectively; Table 2$)$. Mice on the $\mathrm{C}+\mathrm{I}$ and $\mathrm{HP}+\mathrm{I}$ diets ingested $2 \cdot 3$-fold more crude fibre than mice fed $\mathrm{C}$ and HP, respectively $(P<0 \cdot 001$; Table 2$)$. The energy intake derived from carbohydrates relative to fat was higher in HP + I- than in HP-fed mice $(P=0 \cdot 007$; Table 2). The food conversion efficiency was lower in HP- than in $\mathrm{HP}+\mathrm{I}-(P=0.019)$ and $\mathrm{C}+\mathrm{I}-(P=0.009)$ and $\mathrm{C}-$ fed mice $(P=0 \cdot 022$; Table 2$)$.

\section{Energy metabolism and physical activity}

The TEE was lower in mice fed the HP + I than HP, C + I and $\mathrm{C}(P<0.001$; Fig. 2(a)). Similarly, COX tended to be lower in HP + I- compared to HP-fed mice ( $P=0 \cdot 1$; Fig. 2 (b)). In contrast, FOX and RQ were comparable among the groups during the 48-h measuring period (Fig. 2(c) and (d)). The EB was higher in $\mathrm{HP}+\mathrm{I}-$ than in $\mathrm{C}-(P=0.01)$ and $\mathrm{C}$ + I-fed mice $(P=0.02)$; Fig. 2(e)). The EB of HP-fed mice tended to be lower in $\mathrm{C}$ - and $\mathrm{C}+\mathrm{I}$-fed mice $(P=0.09$, respectively), but the physical activity was greater in mice fed the HP than in HP +I, C and C + I $(P<0 \cdot 05$; Fig. $2(\mathrm{f}))$. During the stay in the respiration chambers, the mean body weight was higher in mice fed inulin/FOS-containing diets $(P<0 \cdot 05$, Supplementary Fig. S1(a) of Supplementary material), but the food and energy intakes were comparable among dietary groups (Supplementary Fig. S1(b) and (c) of Supplementary material). The 48 -h water intake was $1 \cdot 5$ 1.6-fold higher in HP- than in C-groups independent of inulin/FOS content $(P<0.05$; Supplementary Fig. S1(d) of Supplementary material).

\section{Faecal $N$ excretion, apparent $N$ digestibility and gastrointestinal transit time}

The amount of faecal excreta and faecal DM were lower in $\mathrm{C}+\mathrm{I}-$ and $\mathrm{HP}+\mathrm{I}$ - compared to those of in $\mathrm{C}-(P<0.05)$ and HP-fed mice $(P<0 \cdot 001$; Table 3$)$. The water loss via faeces tended to be $83 \%$ higher in HP- compared to that of in $\mathrm{HP}+\mathrm{I}$-fed mice $(P=0 \cdot 09$; Table 3$)$. The 48 -h dietary $\mathrm{N}$ intake was lower in C- than in HP-fed mice, independently of inulin/FOS $(P<0 \cdot 001$; Table 3$)$. The 48 -h faecal N excretion was higher in mice fed the HP compared to that of in $\mathrm{C}$ $(P<0.001), \mathrm{C}+\mathrm{I}(P<0.01)$ and HP + I $(P<0.01)$ diets. The faecal $\mathrm{N}$ excretion/intake ratio was significantly lower in $\mathrm{C}$ than in $\mathrm{C}+\mathrm{I}$-fed mice $(P=0.02)$, but did not differ between $\mathrm{HP}$ - and HP + I-fed mice, while it was lower in mice of both HP than of both C-groups $(P=0 \cdot 01)$. Furthermore, mice fed a $\mathrm{C}$ diet had a higher apparent $\mathrm{N}$ digestibility than $\mathrm{C}+\mathrm{I}$-fed mice $(P<0 \cdot 04)$, while it was not different between $\mathrm{HP}$ - and HP + I-fed mice. However, the apparent $\mathrm{N}$ digestibility was higher in $\mathrm{HP}+\mathrm{I}-$ than in $\mathrm{C}+\mathrm{I}$-fed mice $(P<0.001$; Table 3). Inulin/FOS and the dietary protein content had no effect on the gastrointestinal transit time (Table 3). The faecal energy content was significantly higher in mice fed inulincontaining than inulin-free diets $(P<0 \cdot 05)$, while the faecal 
(a)

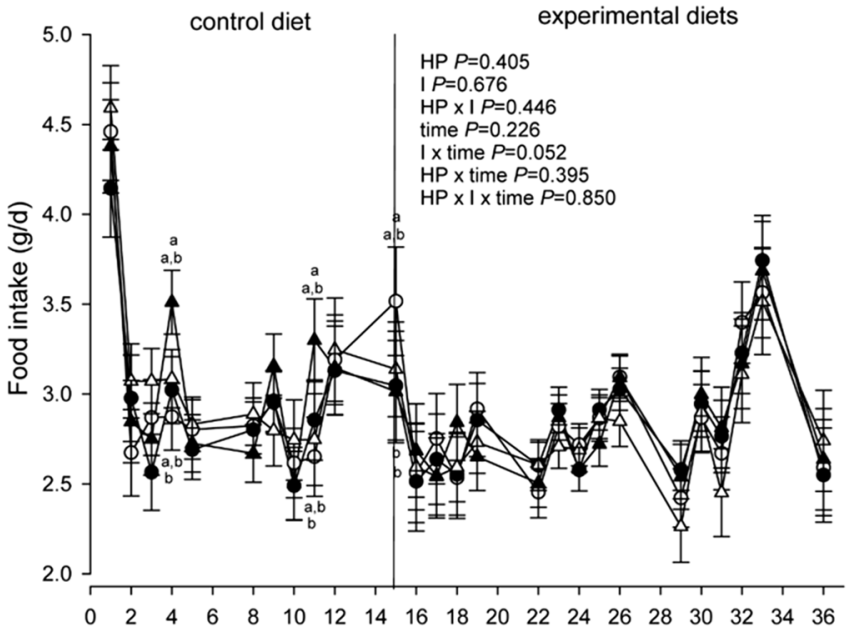

(c)

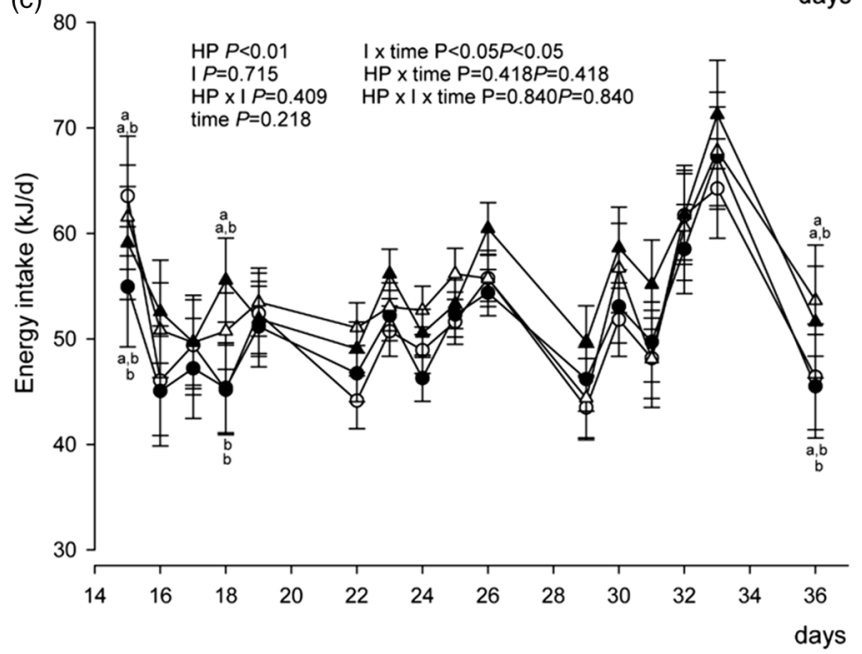

(b)

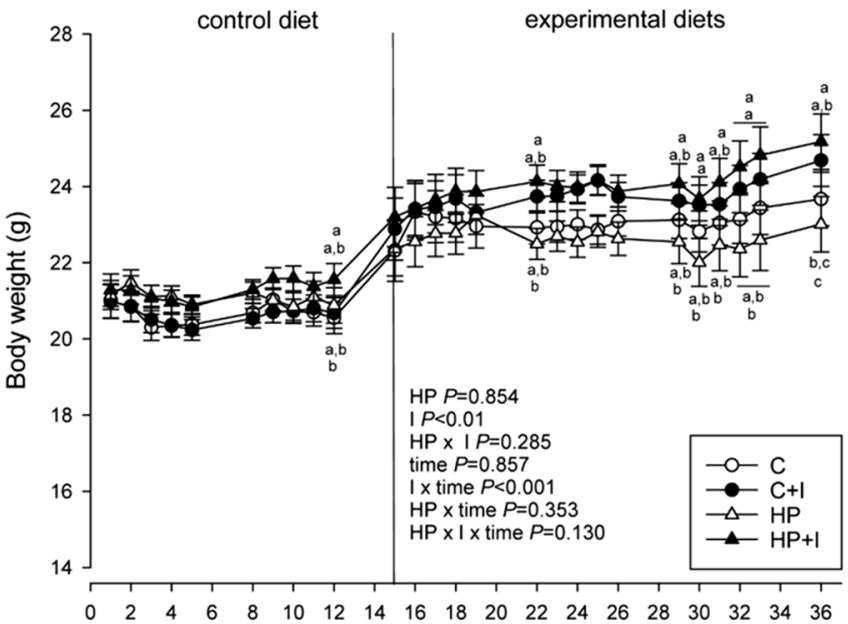

(d)

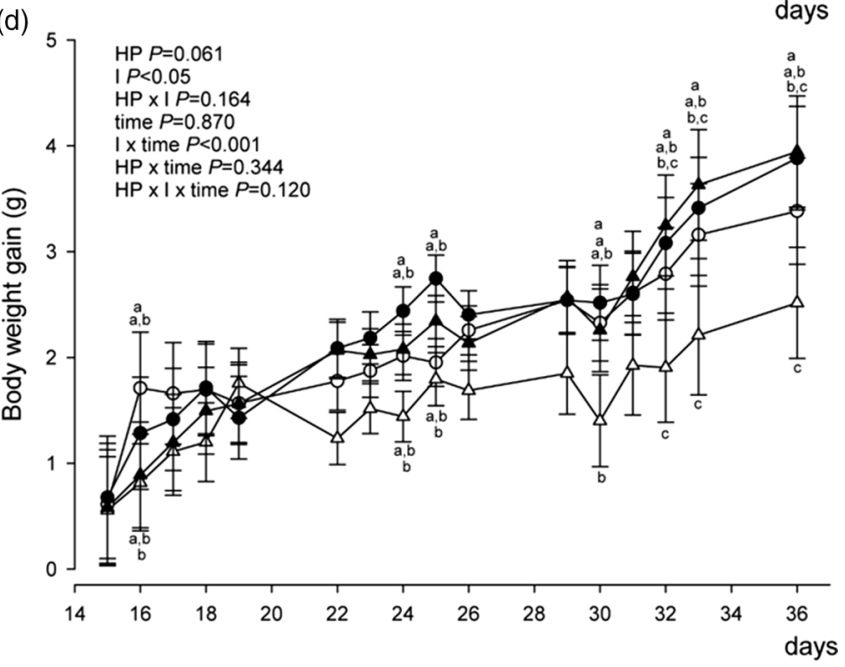

Fig. 1. Food and energy intake, body weight and body weight gain of mice fed a control diet for 2 weeks (adaptation phase) and subsequently one of four experimental diets for 3 weeks: control \pm inulin/FOS $(\mathrm{C} ; \mathrm{C}+\mathrm{I})$ or high-protein diet \pm inulin/FOS $(\mathrm{HP} ; \mathrm{HP}+\mathrm{I})$ diet. Food intake (a) and body weight (b) were recorded in the adaptation and experimental phase. Daily energy intake (c) and body weight gain (d) were calculated from days 15 to 36 of feeding experimental diets. Values are LSM and SE; $n 10$ per diet. Labelled means at one time point without a common letter differ, $P<0.05$ (Tukey-Kramer test).

Table 2. Average food, dry matter, macronutrient and energy intake, the carbohydrate/fat energy intake ratio and food conversion efficiency during 3 weeks feeding of control \pm inulin/FOS $(\mathrm{C} ; \mathrm{C}+\mathrm{I})$ or high-protein diet \pm inulin/FOS $(\mathrm{HP} ; \mathrm{HP}+\mathrm{I})$ diet. $^{1}{ }^{\text {The }}$ macronutrient intake was calculated based on the dry matter content of the respective diet

\begin{tabular}{|c|c|c|c|c|c|c|c|}
\hline \multirow[b]{2}{*}{ Item } & \multirow[b]{2}{*}{ C } & \multirow[b]{2}{*}{$C+1$} & \multirow[b]{2}{*}{ HP } & \multirow[b]{2}{*}{$\mathrm{HP}+\mathrm{I}$} & \multicolumn{3}{|c|}{$P$-value } \\
\hline & & & & & $\mathrm{HP}$ & 1 & $\mathrm{HP} \times \mathrm{I}$ \\
\hline Cumulative food intake (g/3 weeks) & $41.72 \pm 0.91$ & $42.19 \pm 0.91$ & $40.54 \pm 1.02$ & $42.27 \pm 0.98$ & 0.567 & 0.260 & 0.509 \\
\hline Food intake (g/d) & $2.78 \pm 0.06$ & $2.81 \pm 0.06$ & $2.70 \pm 0.07$ & $2.82 \pm 0.07$ & 0.594 & 0.175 & 0.376 \\
\hline Dry matter intake $(\mathrm{g} / \mathrm{d})$ & $2.41 \pm 0.05$ & $2.47 \pm 0.05$ & $2 \cdot 33 \pm 0.06$ & $2.46 \pm 0.05$ & 0.422 & 0.091 & 0.486 \\
\hline Crude protein intake $(\mathrm{g} / \mathrm{d})$ & $0.43 \pm 0.02^{b}$ & $0.44 \pm 0.02^{b}$ & $0.94 \pm 0.02^{\mathrm{a}}$ & $0.99 \pm 0.02^{\mathrm{a}}$ & $<0.001$ & 0.081 & 0.228 \\
\hline Crude fat intake $(\mathrm{g} / \mathrm{d})$ & $0.17 \pm 0.00$ & $0.17 \pm 0.00$ & $0.17 \pm 0.00$ & $0.18 \pm 0.01$ & 0.699 & 0.089 & 0.472 \\
\hline Carbohydrate intake $^{2}(\mathrm{~g} / \mathrm{d})$ & $1.51 \pm 0.02^{\mathrm{a}}$ & $1.38 \pm 0.02^{b}$ & $0.88 \pm 0.03^{c}$ & $0.77 \pm 0.03^{d}$ & $<0.001$ & $<0.001$ & 0.759 \\
\hline Carbohydrate/fat intake ratio & $8.80 \pm 0.004^{a}$ & $7.87 \pm 0.004^{b}$ & $5 \cdot 18 \pm 0.004^{c}$ & $4.27 \pm 0.004^{d}$ & $<0.001$ & $<0.001$ & $<0.01$ \\
\hline Crude fibre intake $(\mathrm{g} / \mathrm{d})$ & $0.12 \pm 0.01^{b}$ & $0.28 \pm 0.01^{a}$ & $0.12 \pm 0.01^{b}$ & $0.28 \pm 0.01^{\mathrm{a}}$ & 0.725 & $<0.001$ & 0.717 \\
\hline Daily energy intake $(\mathrm{kJ} / \mathrm{d})$ & $50 \cdot 20 \pm 1 \cdot 12^{b}$ & $50 \cdot 76 \pm 1 \cdot 12^{b}$ & $52 \cdot 90 \pm 1 \cdot 24^{\mathrm{a}, \mathrm{b}}$ & $55 \cdot 68 \pm 1 \cdot 12^{a}$ & $<0.01$ & 0.166 & 0.349 \\
\hline Total energy intake ( $\mathrm{kJ} / 3$ weeks) & $751 \cdot 0 \pm 17 \cdot 4^{\mathrm{b}}$ & $794 \cdot 3 \pm 19 \cdot 2^{a, b}$ & $759 \cdot 4 \pm 17 \cdot 4^{a, b}$ & $828 \cdot 3 \pm 18 \cdot 5^{b}$ & $<0.01$ & 0.252 & 0.482 \\
\hline Carbohydrate/fat energy ratio & $4 \cdot 16 \pm 0 \cdot 10^{c}$ & $4 \cdot 31 \pm 0 \cdot 10^{b, c}$ & $4.74 \pm 0.11^{\mathrm{b}}$ & $5 \cdot 30 \pm 0.11^{\mathrm{a}}$ & $<0.001$ & $<0.01$ & 0.057 \\
\hline Food conversion efficiency (g BW/MJ) & $4.08 \pm 0.30^{\mathrm{a}}$ & $4 \cdot 24 \pm 0.30^{\mathrm{a}}$ & $2.60 \pm 0.33^{b}$ & $4.09 \pm 0.32^{\mathrm{a}}$ & $<0.05$ & $<0.05$ & $<0.05$ \\
\hline
\end{tabular}

${ }^{1}$ Values are LSM and SE; $n 10$ per dietary group.

${ }^{2}$ Carbohydrates $=$ starch + sucrose + dextrin.

Labelled means in a row without a common letter differ, $P<0.05$ (Tukey-Kramer test). 
(a)

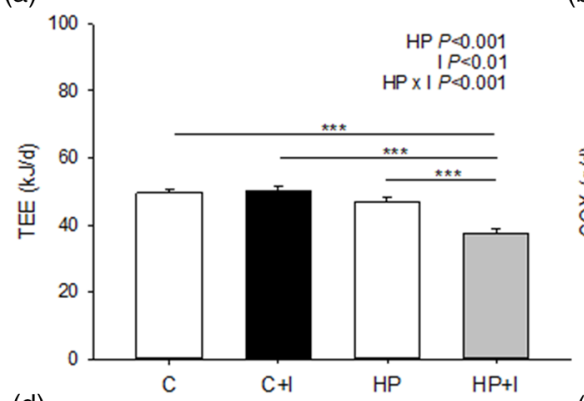

(d)

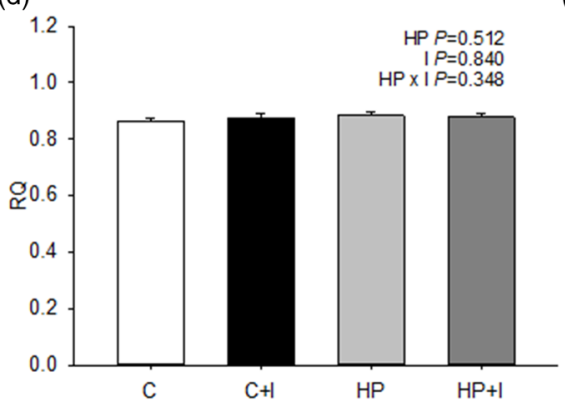

(b)

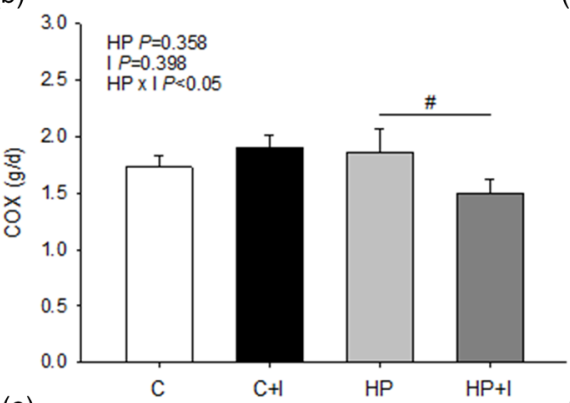

(e)

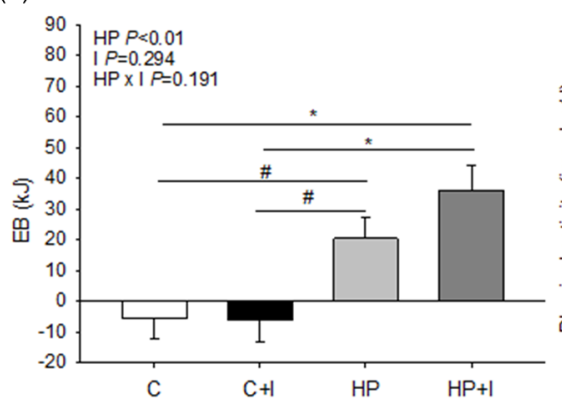

(c)

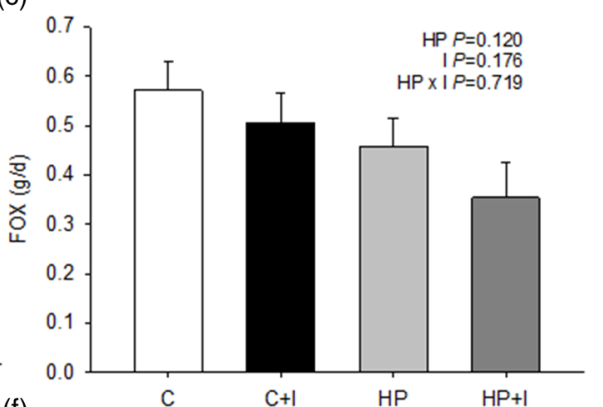

(f)

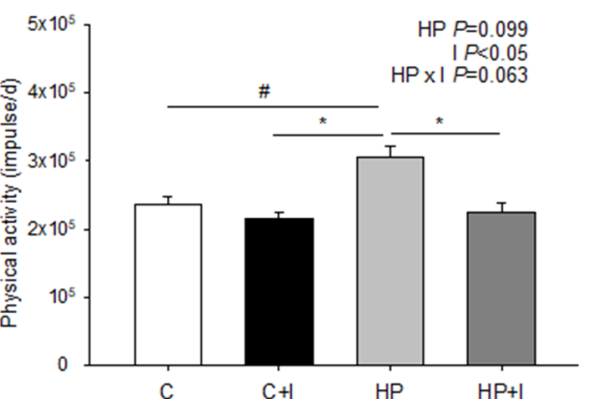

Fig. 2. Components of energy expenditure in mice fed a control \pm inulin/FOS $(C ; C+I)$ or a high-protein diet \pm inulin/FOS (HP; HP $+\mathrm{I})$ diet for 3 weeks. The gas exchange was analysed for $48 \mathrm{~h}$ in respiration chambers. Daily total energy expenditure (TEE) (a), carbohydrate oxidation (COX) (b) and fat oxidation (FOX) (c), each normalised to metabolic body weight (mBW), respiratory quotient (RQ) (d), energy balance (EB) (e) and physical activity (f). Values are LSM and SE; C $n$ 10; $\mathrm{C}+\mathrm{I}, \mathrm{HF}, \mathrm{HF}+\mathrm{I}, \mathrm{HP}, \mathrm{HP}+\mathrm{I} n 9$ per diet. $\# 0.06<P<0.1,{ }^{*} P<0.05,{ }^{* \star} P<0.01,{ }^{\star * \star} P<0.001$ (Tukey-Kramer test).

energy excretion was not different among the dietary groups. In addition, diet digestibility was significantly higher in HP + I- than in C-, C + I- and HP-fed mice $(P<0 \cdot 01$, respectively) and significantly higher in $\mathrm{C}+\mathrm{I}$ - than in $\mathrm{C}$-fed mice $(P=0 \cdot 02$; Table 3$)$.

\section{Faecal microbiota abundance}

The investigation of the faecal microbiota revealed that the DNA abundance of the Bacteroides-Prevotella group was $2 \cdot 3$-fold higher in faeces of mice fed the $\mathrm{C}+\mathrm{I}$ and $\mathrm{HP}+\mathrm{I}$ than in $\mathrm{C}$ diets $(P<0 \cdot 05$; Fig. 3(a)). Faeces in the $\mathrm{C}$ group had a $2 \cdot 3-5 \cdot 1$-fold higher $C$. coccoides group DNA abundance than faeces from $\mathrm{C}+\mathrm{I}-$, HP- and HP + I-groups $(P<0 \cdot 001$; Fig. 3(b)). The faecal $C$. leptum DNA abundance was 4.36.5-fold higher in $\mathrm{C}$ - than in $\mathrm{C}+\mathrm{I}-$ and $\mathrm{HP}+\mathrm{I}$-fed mice $(P<0 \cdot 001$; Fig. 3(c)). The HP + I-fed mice had $79 \%$ lower faecal $C$. leptum DNA abundance than HP-fed mice $(P<$ 0.001; Fig. 3(c)). No significant difference in the relative DNA abundance of faecal Lactobacillus and Enterobacteriaceae was found among the experimental diets (Fig. 3(d) and (e)). The ratio of the Bacteroides-Prevotella group to the total

Table 3. Faecal characteristics and excretions, nitrogen $(\mathrm{N})$ intake, apparent $\mathrm{N}$ digestibility, gastrointestinal transit time and diet digestibility in mice fed a control \pm inulin/FOS $(\mathrm{C} ; \mathrm{C}+\mathrm{I})$ or a high-protein diet \pm inulin/FOS (HP; HP $+\mathrm{I})$ diet for 3 weeks. Data and samples were collected during the 48-h indirect calorimetry measurements ${ }^{1}$

\begin{tabular}{|c|c|c|c|c|c|c|c|}
\hline \multirow[b]{2}{*}{ Item } & \multirow[b]{2}{*}{$\mathrm{C}$} & \multirow[b]{2}{*}{$C+1$} & \multirow[b]{2}{*}{$\mathrm{HP}$} & \multirow[b]{2}{*}{$\mathrm{HP}+\mathrm{I}$} & \multirow[b]{2}{*}{$\mathrm{HP}$} & \multicolumn{2}{|c|}{$P$-value } \\
\hline & & & & & & 1 & $\mathrm{HP} \times \mathrm{I}$ \\
\hline Faecal excretion (g/2 d) & $0.44 \pm 0.02^{\mathrm{a}}$ & $0.36 \pm 0.02^{b}$ & $0.51 \pm 0.02^{\mathrm{a}}$ & $0.35 \pm 0.02^{b}$ & 0.125 & $<0.001$ & 0.075 \\
\hline Faecal dry mass excretion (g/2 d) & $0.41 \pm 0.02^{\mathrm{a}}$ & $0.33 \pm 0.02^{b, c}$ & $0.46 \pm 0.02^{a}$ & $0.32 \pm 0.02^{c}$ & 0.208 & $<0.001$ & $0 \cdot 107$ \\
\hline Faecal water (\%) & $7 \cdot 8 \pm 0.8$ & $7 \cdot 8 \pm 0.8$ & $9.9 \pm 0.9$ & $8.5 \pm 0.9$ & 0.132 & 0.367 & 0.436 \\
\hline Faecal water excretion $(\mathrm{mg} / 2 \mathrm{~d})$ & $35 \cdot 5 \pm 4 \cdot 8^{\mathrm{AB}}$ & $27 \cdot 7 \pm 5 \cdot 2^{\mathrm{AB}}$ & $49 \cdot 1 \pm 5 \cdot 7^{A}$ & $29 \cdot 3 \pm 5 \cdot 5^{\mathrm{B}}$ & 0.182 & $<0.05$ & 0.274 \\
\hline Faecal energy content ${ }^{2}(\mathrm{~kJ} / \mathrm{g})$ & $13 \cdot 8 \pm 0 \cdot 1^{b}$ & $14 \cdot 8 \pm 0 \cdot 1^{\mathrm{a}}$ & $13 \cdot 9 \pm 0.1^{b}$ & $14 \cdot 5 \pm 0.1^{a}$ & 0.378 & $<0.001$ & 0.096 \\
\hline Faecal energy excretion ( $\mathrm{kJ} / 2 \mathrm{~d}$ ) & $11 \cdot 2 \pm 0 \cdot 8$ & $10 \cdot 9 \pm 0.8$ & $13 \cdot 1 \pm 0 \cdot 8$ & $11.9 \pm 0.8$ & 0.081 & 0.359 & 0.604 \\
\hline Faecal $\mathrm{C} / \mathrm{N}$ ratio & $8 \cdot 5 \pm 1 \cdot 2$ & $10 \cdot 5 \pm 1 \cdot 2$ & $8 \cdot 0 \pm 1 \cdot 3$ & $10 \cdot 5 \pm 1 \cdot 3$ & 0.830 & 0.088 & 0.780 \\
\hline Faecal $\mathrm{N}$ excretion (mg/2 d) & $15 \cdot 5 \pm 1.9^{b}$ & $18 \cdot 0 \pm 1.9^{b}$ & $27 \cdot 9 \pm 2 \cdot 1^{\mathrm{a}}$ & $19 \cdot 2 \pm 2 \cdot 0^{\mathrm{b}}$ & $<0.01$ & 0.134 & $<0.05$ \\
\hline $\mathrm{N}$ intake $(\mathrm{mg} / 2 \mathrm{~d})$ & $171 \cdot 0 \pm 15 \cdot 6^{b}$ & $145 \cdot 7 \pm 15 \cdot 6^{b}$ & $426 \cdot 3 \pm 15 \cdot 6^{a}$ & $390 \cdot 1 \pm 15 \cdot 6^{a}$ & $<0.001$ & $<0.05$ & 0.449 \\
\hline Faecal $\mathrm{N}$ excretion/ $\mathrm{N}$ intake ratio & $0.09 \pm 0.01^{b}$ & $0.13 \pm 0.01^{a}$ & $0.06 \pm 0.01^{c, d}$ & $0.05 \pm 0.01^{d}$ & $<0.01$ & $<0.05$ & 0.135 \\
\hline Apparent $\mathrm{N}$ digestibility (\%) & $81 \cdot 5 \pm 1 \cdot 5^{\mathrm{b}}$ & $75 \cdot 1 \pm 1 \cdot 6^{c}$ & $86 \cdot 4 \pm 1 \cdot 7^{\mathrm{a}, \mathrm{b}}$ & $89 \cdot 6 \pm 1 \cdot 7^{a}$ & $<0.001$ & 0.335 & $<0.01$ \\
\hline Gastrointestinal transit time (min) & $367 \pm 66$ & $331 \pm 66$ & $298 \pm 68$ & $316 \pm 68$ & 0.531 & 0.892 & 0.698 \\
\hline Diet digestibility (\%) & $94 \cdot 3 \pm 0.1^{c}$ & $95 \cdot 0 \pm 0 \cdot 2^{b}$ & $94.4 \pm 0.1^{\mathrm{b}, \mathrm{c}}$ & $95 \cdot 9 \pm 0.2^{a}$ & $<0.01$ & $<0.001$ & $<0.05$ \\
\hline
\end{tabular}

${ }^{1}$ Values are LSM and SE; $n 10$ per dietary group, with the exception of transit time were $n 5$ per dietary group.

${ }^{2}$ Faecal samples from $n$ 3-5 mice per diet were pooled for the analysis of faecal energy content by bomb calorimetry.

Labelled means in a row without a common lower case letter differ, $P<0 \cdot 05$; labelled means in a row without a common upper case letter differ, $P<0.1$ (Tukey-Kramer test). 
(a)

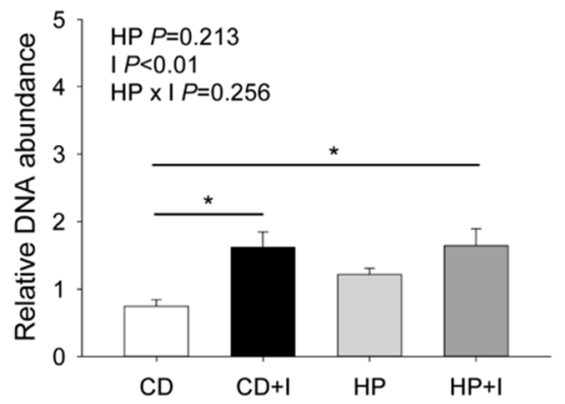

(d)

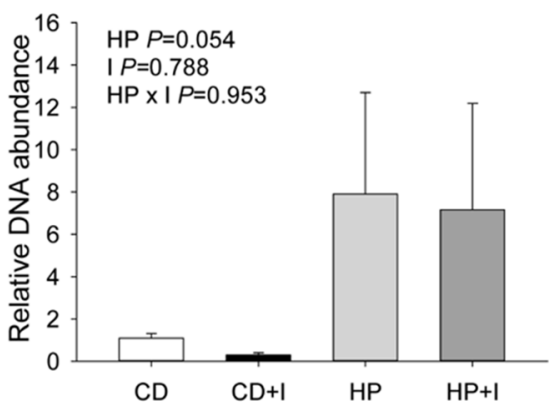

(b)

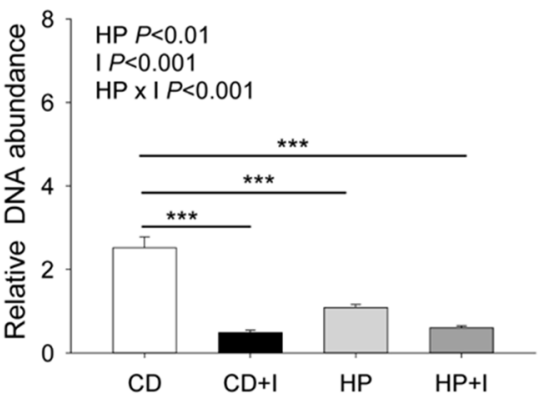

(e)

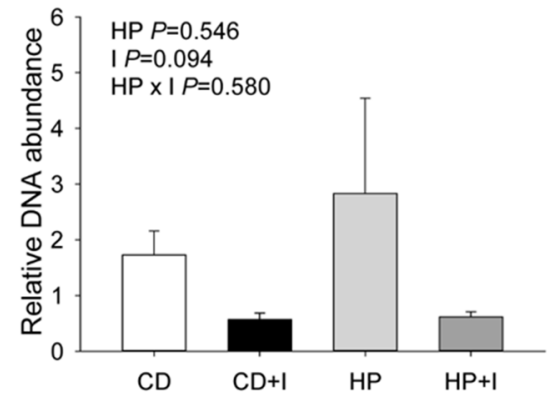

(c)

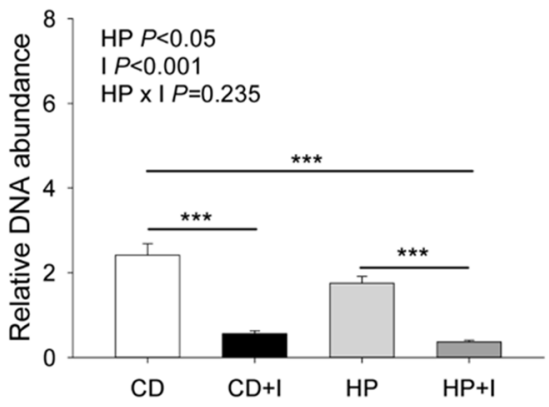

(f)

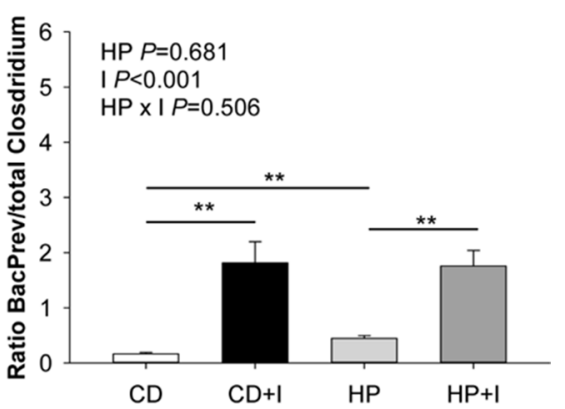

Fig. 3. Faecal microbiota groups in mice fed a control \pm inulin/FOS $(C ; C+I)$ or a high-protein diet \pm inulin/FOS (HP; HP $+\mathrm{I})$ diet for 3 weeks. (a) BacteroidesPrevotella group, (b) Clostridium coccoides group, (c) Clostridium leptum, (d) Lactobacillus, (e) Enterobacteriaceae and (f) the ratio of Bacteroides-Prevotella group to total Clostridium abundance. Values are LSM and SE; $n 10$ per diet. ${ }^{*} P<0.05,{ }^{* *} P<0.01,{ }^{\star * \star} P<0.001$ (Tukey-Kramer test).

Clostridium abundance was 3.8-10.7-fold higher in inulin/ FOS-supplemented compared to $\mathrm{C}$ - and HP-fed groups $(P<0 \cdot 01$, Fig. 3(f)). Besides, mice fed the HP diet showed a 2.7-fold higher ratio between the Bacteroides-Prevotella group and total Clostridium abundance than $\mathrm{C}$-fed mice $(P<0 \cdot 01)$. We found significant inverse correlations between the abundances of the Bacteroides-Prevotella group and C. leptum and the $C$. coccoides group, respectively (Supplementary Table S2 of Supplementary material). The abundance of the $C$. coccoides group was positively correlated with $C$. leptum and Enterobacteriaceae, respectively. Furthermore, there was a positive correlation between Lactobacillus and Enterobacteriaceae abundances.

Table 4. Spearman correlation coefficients between the abundance of faecal microbial groups, energy expenditure, nutrient oxidation, energy intake, faecal nitrogen $(\mathrm{N})$ excretion and apparent $\mathrm{N}$ digestibility

\begin{tabular}{lrrrrr}
\hline Item & BacPrev & ClosCos & ClosLep & Lacto & Entero \\
\hline TEE & -0.291 & 0.109 & $0.352^{\star}$ & $-0.371^{*}$ & -0.013 \\
COX & -0.111 & 0.011 & 0.193 & -0.088 & -0.057 \\
FOX & -0.105 & 0.127 & 0.105 & -0.068 & 0.103 \\
RQ & 0.042 & -0.044 & 0.048 & 0.011 & -0.088 \\
Energy intake & 0.039 & -0.043 & -0.093 & $0.397^{\star}$ & -0.027 \\
Faecal N excretion & -0.028 & -0.041 & 0.118 & 0.152 & -0.073 \\
Apparent N & 0.205 & 0.004 & -0.150 & $0.548^{*}$ & 0.095 \\
$\quad$ digestibility & & & & & \\
\hline
\end{tabular}

BacPrev, Bacteroides-Prevotella group; ClosCos, Clostridium coccoides group; ClosLep, Clostridium leptum; Lacto, Lactobacillus; Entero, Enterobacteriaceae.

${ }^{*} P<0.05$.

\section{Correlation between microbiota abundances, Respiratory Quotient, energy expenditure, apparent $N$ digestibility and faecal $N$ excretion}

A positive correlation was found between $C$. leptum abundance and TEE (Table 4). Lactobacillus abundances correlated inversely with TEE, but directly with energy intake and apparent $\mathrm{N}$ digestibility.

\section{Discussion}

In contrast to our expectations, 3-week feeding of an HP diet containing inulin/FOS increased body weight gain in C57BL/ 6 mice above the level of $\mathrm{C}$-fed mice, while feeding the HP diet alone reduced body weight gain relative to $\mathrm{HP}+\mathrm{I}$ - and $\mathrm{C}$-fed mice. This could not be explained by differences in energy intake, which did not differ among the groups. Mice in the HP + I compared to those in the HP group consumed a greater proportion of fat relative to carbohydrates, which corresponds to a greater portion of energy intake from fat. We and others have reported earlier that HP diets can reduce food intake and body weight in normal-weight mice ${ }^{(17,41-43)}$. However, we did not observe an effect of inulin/FOS included in the $\mathrm{C}$ diet on food intake and body weight gain. Our finding is in line with previous experiments in BALB/c mice in which no effects on body weight were observed when a control diet was supplemented with $10 \%$ of different fermentable dietary fibres, such as inulin, FOS, XOS, galacto-oligosaccharide (GOS), apple pectin, polydextrose or beta-glucan for 3 weeks of feeding ${ }^{(44)}$. Likewise in rats, feeding a $55 \%$ HP diet containing $10 \%$ FOS for 5 weeks had no 
effect on body weight and fat mass compared to controls albeit the energy intake was $10 \%$ lower in the HP diet with FOS than in the control diet ${ }^{(45)}$. In contrast, rats fed with a high-fat diet $(40 \%)$ containing $10 \%$ inulin for 3 weeks decreased cumulative food intake but not body weight and fat mass ${ }^{(46)}$. Based on these findings, it can be concluded that the dietary protein and fat levels exert a major influence on inulin/FOS's effect on body weight gain.

In order to elucidate the potential underlying mechanisms, we investigated the energy expenditure, carbohydrate and fat oxidation and energy balance over a 48 -h time period after 3 weeks on the experimental diets. In $\mathrm{HP}+\mathrm{I}$-fed mice, the $15 \%$ lower carbohydrate intake resulted in a $17 \%$ lower carbohydrate-to-fat intake ratio which is reflected by the $19 \%$ difference in COX between HP + I- and HP-fed mice. The 42-fold higher energy balance (EB) in HP + I- than in $\mathrm{C}$ - and $\mathrm{C}+\mathrm{I}$-fed mice pointed to a strong impact of the lower TEE on EB in the HP + I group. Although $\mathrm{C}$ - and $\mathrm{C}+\mathrm{I}$-fed mice still gained body weight in week 4 on the experimental diet, $\mathrm{C}$ - and $\mathrm{C}+\mathrm{I}$-fed mice were in slightly negative $\mathrm{EB}$ during the $2 \mathrm{~d}$ of indirect calorimetry measurement, which was due to lower food intake in the respiration chamber. Of note, the body weight change (before and after indirect calorimetry measurement) was not altered among the dietary groups. However, inulin/FOS in the $\mathrm{C}$ diet had no impact on TEE, EB, physical activity, respiratory quotient (RQ), carbohydrate and fat oxidation when compared to C. A previous study revealed that feeding a $60 \% \mathrm{HP}$ diet to C57BL/6 mice for 12 weeks reduced TEE compared to mice fed a control diet ${ }^{(17)}$, which, however, was not apparent in HP- and $\mathrm{C}$-fed mice in our study. This is likely due to the higher dietary protein content used in the earlier study ${ }^{(17)}$. However, as indicated by the lower TEE, HP + I-fed mice dissipated less dietary energy as heat, had lower physical activity, and gained more body mass than HP-fed mice, suggesting that mice fed the HP + I were more effective in converting dietary energy into body mass as underlined by the higher diet digestibility and food conversion efficiency. It seems that the higher starch content of the HP diet provides more glucose which is preferably oxidised, while, inulin/FOS in the HP + I diet, which can be completely fermented in the colon and caecum, deliver more short-chain fatty acids (SCFA). For example, SCFA infused in the caecum of mice are substrates for glucose, cholesterol and lipid synthesis ${ }^{(47)}$, but if this mechanism is entirely responsible to deposit more body mass in $\mathrm{HP}+\mathrm{I}$-fed mice remains to be investigated. In addition, it remains unclear if the higher body mass gain of HP + I-fed mice is a result of an increase in body fat or muscle mass. Unfortunately, we did not measure body composition in our study, but recently, it has been reported that rats fed with a $55 \%$ high-protein diet with and without $10 \%$ FOS for 5 weeks did not differ in body composition, even compared to the control group ${ }^{(45)}$.

The question arose, if energy metabolism is related to gut microbiota. Therefore, we performed correlation analyses between faecal gut microbiota abundances and energy expenditure, RQ and nutrient oxidation. Interestingly, TEE was positively correlated with the abundance of $C$. leptum and negatively correlated with Lactobacillus, but not with COX. In contrast to our finding, feeding a whey-inulin compared to a wheycellulose diet to obesity-prone (OPCD) rats reduced the copy number of Lactobacillus and energy expenditure ${ }^{(48)}$, pointing to a direct correlation between Lactobacillus and energy expenditure. Conclusively, the negative correlation between TEE and the abundance of Lactobacillus in the present study is mainly driven by the dietary protein but not by inulin/ FOS content.

Mice fed the HP diet showed higher physical activity than C-, C + I- and HP + I-fed mice. Earlier studies reported no significant increase in physical activity in mice in response to HP relative to $C$ feeding ${ }^{(17,49)}$. The discrepancy between earlier ${ }^{(17,49)}$ and our results may be due to the difference in feeding duration (3 weeks $v .12$ weeks) or dietary protein concentration (40\% v. $60 \%$ or $47.9 \%$ protein), whereas the mouse strain was the same in all studies. The greater water intake with $\mathrm{HP}$ than $\mathrm{C}$ feeding is in concordance with an earlier study, demonstrating that $60 \% \mathrm{HP}$ diet feeding for 12 weeks led to $75 \%$ higher water intake than $\mathrm{C}$ diet feeding in C57BL/ 6 mice $^{(17)}$. The higher water intake with the HP diet is due to the increase in protein degradation and the need for greater urinary urea excretion ${ }^{(50)}$, independently of the inulin/FOS content in our study.

High-protein diets are incompletely digested accompanied by high faecal $\mathrm{N}$ excretion ${ }^{(51)}$. Our present results reveal that the inclusion of inulin/FOS in an HP diet reduces the amount of faecal $\mathrm{N}$ excretion without altering the transit time of the digest. In contrast to our findings, the addition of $7.5 \%$ FOS or XOS in place of starch increased faecal $\mathrm{N}$ excretion while it reduced renal excretion of $\mathrm{N}$ by $20-30 \%$ compared to fibre-free control diet in rats ${ }^{(8)}$. Adult dogs receiving a diet containing $1 \%$ FOS for 3 weeks showed unaltered urinary $\mathrm{N}$ excretion and unaltered nitrogen balance compared to those with the control diet ${ }^{(52)}$. Fewer studies focused on $\mathrm{N}$ intake and $\mathrm{N}$ balance while feeding an HP diet. Feeding HP diets supplemented with inulin $(12.5 \mathrm{~g} / \mathrm{kg} \mathrm{DM})$ increased faecal $\mathrm{N}$ excretion and decreased the ratio of urinary to faecal $\mathrm{N}$ output compared with inulin-free diet feeding of finishing pigs ${ }^{(51)}$. However, the $30 \%$ lower faecal $\mathrm{N}$ excretion on the $\mathrm{HP}+\mathrm{I}$ compared to the HP diet in the present study might be partly related to the higher apparent $\mathrm{N}$ digestibility, while the ratio of faecal $\mathrm{N}$ excretion/ $\mathrm{N}$ intake was not different between $\mathrm{HP}+$ I- and HP-fed mice. We show here that mice on the HP diet had higher faecal water content than with $\mathrm{HP}+\mathrm{I}$ feeding, while the faecal water content of $\mathrm{C}$-fed mice was comparable to $\mathrm{C}+\mathrm{I}$ - and HP + I-fed mice. The reason for the higher faecal water content with HP feeding but not with the inclusion of inulin/FOS may be linked to the increase of undigested protein reaching the colon and increasing proteolytic fermentation $^{(53)}$. The proteolytic fermentation favours higher osmotic pressure and therefore greater water transfer into the intestinal lumen ${ }^{(53)}$. Inulin and FOS do not seem to induce higher faecal water excretion as shown in our study. Comparably, Pinna et al. found no differences in faecal water content when adult dogs received $1.5 \mathrm{~g}$ FOS $/ \mathrm{kg} \mathrm{DM}$ to a low- or high-protein diet for $28 \mathrm{~d}^{(53)}$.

In the large intestine, a vast range of bacterial species grow and are specialised for a particular ecological niche ${ }^{(54)}$. 
Prebiotics and amino acids represent the main energy substrate for bacteria promoting microbial growth ${ }^{(2,27,28,35)}$. While there has been an extensive focus on the bifidogenic effect of inulin ${ }^{(2,55,56)}$, only few reports describe the inulin/FOS effect on other bacteria species. Species belonging to the genus Bacteroides are versatile polysaccharide- and FOS-fermenters ${ }^{(2,7)}$. Our present findings show a higher faecal DNA abundance of the Gram-negative Bacteroides-Prevotella group after feeding $\mathrm{C}+\mathrm{I}$ and $\mathrm{HP}+\mathrm{I}$ than $\mathrm{C}$. Feeding a highfibre diet containing $21.6 \%$ inulin/FOS (1:1) until the age of 25 weeks led to higher Bacteroides-Prevotella DNA abundances than in rats fed a control diet ${ }^{(57)}$. Furthermore, saccharolytic gut bacteria belong to the Clostridium or Lactobacillus genus ${ }^{(2)}$. Our findings of reduced C. coccoides and C. leptum DNA abundances in faeces of HP + I- and C + I-fed mice are in accordance with the results of previous studies describing reduced C. coccoides and C. leptum DNA abundances in the faeces of rats after feeding with a high-fibre diet with $21.6 \%$ inulin/ FOS until 25 weeks of age compared to C or HP diet feeding $^{(57)}$. A higher Bacteroides-Prevotella to total Clostridium ratio was visible in both inulin/FOS groups reflecting a shift in the microbiota composition by prebiotics independent of the dietary background. Our relative quantification of Lactobacillus and Enterobacteriaceae did not reveal differences related to inulin/ FOS of either an HP or a $\mathrm{C}$ diet.

Additional analysis revealed a moderately positive correlation between Lactobacillus DNA abundance, apparent $\mathrm{N}$ digestibility and energy intake. This effect is again likely due to the different dietary protein levels, because an increase of protein in the diet has been shown to increase the abundance of Lactobacillaceae ${ }^{(58)}$. In contrast to our findings, feeding of an HP + I diet (200 g protein and $12.5 \mathrm{~g}$ inulin $/ \mathrm{kg} \mathrm{DM}$ ) to finishing pigs for 3 weeks did not alter apparent $\mathrm{N}$ digestibility, Lactobacilli spp. abundances in the colon ${ }^{(51)}$.

Although genders may differently respond to the same $\operatorname{diet}^{(59)}$, the present study investigated the effect of inulin/ FOS in a high-protein diet only in male mice, and thus potential sex differences between diets need to be investigated in future studies. Another aspect is the dosage of inulin/FOS fed to mice, which translates to $43-44 \mathrm{~g}$ inulin/FOS/day for a $60-90 \mathrm{~kg}$ adult man. Such amount can be critical, as inulin dosages $>15 \mathrm{~g} / \mathrm{d}$ can induce undesirable side effects, e.g. flatulence, abdominal pain and bloating ${ }^{(12,13)}$. Levels $\geq 20 \mathrm{~g}$ of inulin/FOS per day have been shown to induce cramps and abdominal pain in humans ${ }^{(60)}$.

Another limitation of the present study is that we measured only a selected and limited number of microbiota candidates known from the literature to be responsive to prebiotics. In the future, a microbiome study should be performed to elucidate further species involved in the adaptation to HP + I feeding.

In summary, our results demonstrate that, in contrast to our hypothesis, the inclusion of $10 \%$ inulin/FOS to a $40 \% \mathrm{HP}$ diet did not reduce body weight gain as compared to the HP diet. Rather, HP + I feeding increased digestibility and body weight gain, but reduced total energy expenditure, physical activity, faecal $\mathrm{N}$ excretion and C. leptum DNA abundance compared to HP diet feeding. Thus, feeding an HP diet containing inulin/FOS altered the intermediary metabolism and mildly affected the gut microbiota. Our data indicate that mice fed the HP + I diet converted nutrients into body mass more effectively than counterparts fed the HP diet alone and achieved comparable body weight gain as mice fed the $\mathrm{C}$ diet. However, the inclusion of inulin/FOS to the $\mathrm{C}$ diet did not alter body weight gain, nutrient utilisation efficiency and energy expenditure, indicating that the combination of the dietary protein level and inulin/FOS is the major driver of the metabolic changes observed.

\section{Supplementary material}

The supplementary material for this article can be found at https://doi.org/10.1017/jns.2021.42.

\section{Acknowledgements}

For the technical assistance and animal care, we gratefully acknowledge the Lab Animal Facility technicians for breeding and housing, the staff at the 'Tiertechnikum' for the realisation of feeding and indirect calorimetry measurements and Hilke Brandt for analysing the faecal microbiota. We thank Detlef Schulz-Bull and Susanne Schöne from IOW, Warnemünde, for $\mathrm{N}$ analysis. We acknowledge bomb caloric work performed by Anja Voigt and colleagues from the German Institute of Human Nutrition, Potsdam-Rehbrücke. Inulin and oligofructose were a gift from Beneo.

This work was supported by the core budget of FBN.

F. K., H. M. H., M. M., C. C. M. and B. K. jointly designed the research; F. K., M. L. and M. D. conducted the research; F. K. and A. T. analysed the data and F. K., C. C. M. and B. K. wrote the paper while H. M. H. and M. M. contributed to the interpretation of the data. B. K. had primary responsibility for the final content. All authors read and approved the final manuscript.

All authors declare no conflict of interest. Study data are stored at FBN and are available on request.

\section{References}

1. Pourghassem Gargari B, Dehghan P, Aliasgharzadeh A, et al. (2013) Effects of high performance inulin supplementation on glycemic control and antioxidant status in women with type 2 diabetes. Diabetes Metab J 37, 140-148.

2. Gibson GR \& Roberfroid MB (1995) Dietary modulation of the human colonic microbiota: introducing the concept of prebiotics. J Nutr 125, 1401-1412.

3. Niness KR (1999) Inulin and oligofructose: what are they? J Nutr 129, 1402S-1406S.

4. Reimer RA \& Russell JC (2008) Glucose tolerance, lipids, and GLP-1 secretion in JCR:LA-cp rats fed a high protein fiber diet. Obesity 16, 40-46.

5. Kaur N \& Gupta AK (2002) Applications of inulin and oligofructose in health and nutrition. $J$ Biosci 27, 703-714.

6. Li D, Kim JM, Jin Z, et al. (2008) Prebiotic effectiveness of inulin extracted from edible burdock. Anaerobe 14, 29-34.

7. Macy JM \& Probst I (1979) The biology of gastrointestinal bacteroides. Annu Rev Microbiol 33, 561-594. 
8. Younes H, Garleb K, Behr S, et al. (1995) Fermentable fibers or oligosaccharides reduce urinary nitrogen excretion by increasing urea disposal in the rat cecum. J Nutr 125, 1010-1016.

9. Du H, van der AD, Boshuizen HC, et al. (2010) Dietary fiber and subsequent changes in body weight and waist circumference in European men and women. Am J Clin Nutr 91, 329-336.

10. Tucker LA \& Thomas KS (2009) Increasing total fiber intake reduces risk of weight and fat gains in women. J Nutr 139, 576-581.

11. Delzenne NM, Cani PD \& Neyrinck AM (2007) Modulation of glucagon-like peptide 1 and energy metabolism by inulin and oligofructose: experimental data. J Nutr 137, 2547S-2551S.

12. Cummings JH, Macfarlane GT \& Englyst HN (2001) Prebiotic digestion and fermentation. Am J Clin Nutr 73, 415S-420S.

13. Kruse HP, Kleessen B \& Blaut M (1999) Effects of inulin on faecal bifidobacteria in human subjects. Br J Nutr 82, 375-382.

14. Santesso N, Akl EA, Bianchi M, et al. (2012) Effects of higher- versus lower-protein diets on health outcomes: a systematic review and meta-analysis. Eur J Clin Nutr 66, 780-788.

15. Phillips SM (2014) A brief review of higher dietary protein diets in weight loss: a focus on athletes. Sports Med 44, Suppl. 2, S149-S153.

16. Zebrowska E, Maciejczyk M, Zendzian-Piotrowska M, et al. (2019) High protein diet induces oxidative stress in rat cerebral cortex and hypothalamus. Int J Mol Sci 20, 1547.

17. Vu JP, Luong L, Parsons WF, et al. (2017) Long-term intake of a high-protein diet affects body phenotype, metabolism, and plasma hormones in mice. J Nutr 147, 2243-2251.

18. Geiker NRW, Toennesen LL, Astrup A, et al. (2018) The efficacy of a high protein/low glycemic index diet intervention in non-obese patients with asthma. Eur J Clin Nutr 72, 511-516.

19. Morenga L T, Docherty P, Williams S, et al. (2017) The effect of a diet moderately high in protein and fiber on insulin sensitivity measured using the dynamic insulin sensitivity and secretion test (DISST). Nutrients 9, 1291.

20. Stepien M, Gaudichon C, Azzout-Marniche D, et al. (2010) Postprandial nutrient partitioning but not energy expenditure is modified in growing rats during adaptation to a high-protein diet. J Nutr 140, 939-945.

21. Tremblay F, Lavigne C, Jacques H, et al. (2007) Role of dietary proteins and amino acids in the pathogenesis of insulin resistance. Annu Rev Nutr 27, 293-310.

22. Pesta DH \& Samuel VT (2014) A high-protein diet for reducing body fat: mechanisms and possible caveats. Nutr Metab 11, 53.

23. Stepien M, Gaudichon C, Fromentin G, et al. (2011) Increasing protein at the expense of carbohydrate in the diet down-regulates glucose utilization as glucose sparing effect in rats. PLOS ONE 6, e14664.

24. Petzke KJ, Friedrich M, Metges CC, et al. (2005) Long-term dietary high protein intake up-regulates tissue specific gene expression of uncoupling proteins 1 and 2 in rats. Eur J Nutr 44, 414-421.

25. Bray GA, Smith SR, de Jonge L, et al. (2012) Effect of dietary protein content on weight gain, energy expenditure, and body composition during overeating: a randomized controlled trial. Jama 307, 47-55.

26. Luscombe ND, Clifton PM, Noakes M, et al. (2003) Effect of a high-protein, energy-restricted diet on weight loss and energy expenditure after weight stabilization in hyperinsulinemic subjects. Int J Obes Relat Metab Disord 27, 582-590.

27. Andriamihaja M, Davila AM, Eklou-Lawson M, et al. (2010) Colon luminal content and epithelial cell morphology are markedly modified in rats fed with a high-protein diet. Am J Physiol Gastrointest Liver Physiol 299, G1030-G1037.

28. Russell WR, Gratz SW, Duncan SH, et al. (2011) High-protein, reduced-carbohydrate weight-loss diets promote metabolite profiles likely to be detrimental to colonic health. Am J Clin Nutr 93, 10621072.

29. Walker AW, Duncan SH, McWilliam Leitch EC, et al. (2005) Ph and peptide supply can radically alter bacterial populations and short-chain fatty acid ratios within microbial communities from the human colon. Appl Environ Microbiol 71, 3692-3700.
30. Liu X, Blouin JM, Santacruz A, et al. (2014) High-protein diet modifies colonic microbiota and luminal environment but not colonocyte metabolism in the rat model: the increased luminal bulk connection. Am J Physiol Gastrointest Liver Physiol 307, G459-G470.

31. Ambery AG, Tackett L, Penque BA, et al. (2014) Effect of Corncob bedding on feed conversion efficiency in a high-fat diet-induced prediabetic model in C57Bl/6J mice. J Am Assoc Lab Anim Sci 53, 449-451.

32. Derno D, Langhammer M, Renne U, et al. (2012) Mice long-term selected for high body mass are more susceptible to body fat deposition in response to a high fat diet due to insufficient increase in heat production. Archiv Tierzucht 6, 633-646.

33. Weir JB (1949) New methods for calculating metabolic rate with special reference to protein metabolism. J Physiol 109, 1-9.

34. Simonson DC \& DeFronzo RA (1990) Indirect calorimetry: methodological and interpretative problems. Am J Physiol 258, E399E412.

35. Do TT, Hindlet P, Waligora-Dupriet AJ, et al. (2014) Disturbed intestinal nitrogen homeostasis in a mouse model of high-fat diet-induced obesity and glucose intolerance. Am J Physiol Endocrinol Metab 306, E668-E680.

36. Weitkunat K, Schumann S, Petzke KJ, et al. (2015) Effects of dietary inulin on bacterial growth, short-chain fatty acid production and hepatic lipid metabolism in gnotobiotic mice. J Nutr Biochem 26, 929-937.

37. Anitha M, Reichardt F, Tabatabavakili S, et al. (2016) Intestinal dysbiosis contributes to the delayed gastrointestinal transit in high-fat diet fed mice. Cell Mol Gastroenterol Hepatol 2, 328-339.

38. Ruijter JM, Pfaffl MW, Zhao S, et al. (2013) Evaluation of qPCR curve analysis methods for reliable biomarker discovery: bias, resolution, precision, and implications. Methods 59, 32-46.

39. Zheng J, Wittouck S, Salvetti E, et al. (2020) A taxonomic note on the genus Lactobacillus: description of 23 novel genera, emended description of the genus Lactobacillus Beijerinck 1901, and union of Lactobacillaceae and Leuconostocaceae. Int I Syst Evol Microbiol 70, 2782-2858.

40. Tschop MH, Speakman JR, Arch JR, et al. (2011) A guide to analysis of mouse energy metabolism. Nat Methods 9, 57-63.

41. Kucia M, Langhammer M, Gors S, et al. (2011) High-protein diet during gestation and lactation affects mammary gland mRNA abundance, milk composition and pre-weaning litter growth in mice. Animal 5, 268-277.

42. Chang GR, Chiu YS, Wu YY, et al. (2015) Rapamycin impairs HPD-induced beneficial effects on glucose homeostasis. $\mathrm{Br} J$ Pharmacol 172, 3793-3804.

43. Chalvon-Demersay T, Even PC, Tome D, et al. (2016) Low-protein diet induces, whereas high-protein diet reduces hepatic FGF21 production in mice, but glucose and not amino acids up-regulate FGF21 in cultured hepatocytes. J Nutr Biochem 36, 60-67.

44. Petersen A, Heegaard PM, Pedersen AL, et al. (2009) Some putative prebiotics increase the severity of Salmonella enterica serovar Typhimurium infection in mice. BMC Microbiol 9, 245.

45. Hadri Z, Rasoamanana R, Fromentin G, et al. (2017) Fructo-oligosaccharides reduce energy intake but do not affect adiposity in rats fed a low-fat diet but increase energy intake and reduce fat mass in rats fed a high-fat diet. Physiol Behav 182, 114-120.

46. Singh A, Zapata RC, Pezeshki A, et al. (2018) Inulin fiber dosedependently modulates energy balance, glucose tolerance, gut microbiota, hormones and diet preference in high-fat-fed male rats. J Nutr Biochem 59, 142-152.

47. den Besten G, Lange K, Havinga R, et al. (2013) Gut-derived shortchain fatty acids are vividly assimilated into host carbohydrates and lipids. Am J Physiol Gastrointest Liver Physiol 305, G900-G910.

48. Avirineni BSS (2021) Dietary protein interacts with prebiotic fiber to modulate energy balance and body composition. PRISM. Master Thesis, University of Calgary's Digital Repository.

49. Kim JH, Park Y, Kim D, et al. (2012) Dietary influences on nonexercise physical activity and energy expenditure in C57BL/6j mice. J Food Sci 77, H63-H68. 
50. Scharrer E \& Hosser M (1980) Effect of feeding a high protein diet on solute-coupled water absorption from rat colon. Pflugers Arch 388, 165-168.

51. Lynch MB, Sweeney T, Callan BFJJ, et al. (2007) The effect of high and low dietary crude protein and inulin supplementation on nutrient digestibility, nitrogen excretion, intestinal microflora and manure ammonia emissions from finisher pigs. Animal 1, 11121121.

52. Beynen AC, Baas JC, Hoekemeijer PE, et al. (2002) Faecal bacterial profile, nitrogen excretion and mineral absorption in healthy dogs fed supplemental oligofructose. I Anim Physiol Anim Nutr (Berl) 86, 298-305.

53. Pinna C, Vecchiato CG, Bolduan C, et al. (2018) Influence of dietary protein and fructooligosaccharides on fecal fermentative endproducts, fecal bacterial populations and apparent total tract digestibility in dogs. BMC Vet Res 14, 106.

54. Gill T, Asquith M, Rosenbaum JT, et al. (2015) The intestinal microbiome in spondyloarthritis. Curr Opin Rheumatol 27, 319-325.
55. Rastall RA, Gibson GR, Gill HS, et al. (2005) Modulation of the microbial ecology of the human colon by probiotics, prebiotics and synbiotics to enhance human health: an overview of enabling science and potential applications. FEMS Microbiol Ecol 52, 145-152.

56. Roberfroid M, Gibson GR, Hoyles L, et al. (2010) Prebiotic effects: Metabolic and health benefits. Br J Nutr 104, Suppl. 2, S1-S63.

57. Saha DC \& Reimer RA (2014) Long-term intake of a high prebiotic fiber diet but not high protein reduces metabolic risk after a high fat challenge and uniquely alters gut microbiota and hepatic gene expression. Nutr Res 34, 789-796.

58. McAllan L, Skuse P, Cotter PD, et al. (2014) Protein quality and the protein to carbohydrate ratio within a high fat diet influences energy balance and the gut microbiota in C57BL/6j mice. PLOS ONE 9, e88904.

59. Kanter R \& Caballero B (2012) Global gender disparities in obesity: a review. Adv Nutr 3, 491-498.

60. Grabitske HA \& Slavin JL (2009) Gastrointestinal effects of lowdigestible carbohydrates. Crit Rev Food Sci Nutr 49, 327-360. 